Biografistyka Pedagogiczna

Rok 5 (2020) nr 1

ISSN 2543-6112; e-ISSN 2543-7399

DOI: 10.36578/BP.2020.05.09

Danuta Kocurek ${ }^{\star}$

\title{
Egodokumenty - źródłem biograficznym nauczycieli Śląska Cieszyńskiego (na przykładzie wybranych pamiętników)
}

\section{Egodocuments as Biographical Sources Concerning Teachers from Cieszyn Silesia (Using the Examples of Selected Diaries)}

\begin{abstract}
The complicated history of Cieszyn Silesia in the 19th and 2oth centuries has been described in personal documents, including the diaries of teachers Jan Kubisz, Jan Żebrok, and Jan Szuścik. In addition to autobiographies, these sources present sociocultural, educational and political events in this region. This study is focused on selected contents of the diaries and their significance in presenting the historical context and the teachers' work.
\end{abstract}

Keywords: personal documents, biographies, Cieszyn Silesia, diaries, teachers, Jan Kubisz, Jan Żebrok, Jan Szuścik.

* Danuta Kocurek (oooo-0oo2-9670-8382) - dr, adiunkt na Wydziale Etnologii i Nauk o Edukacji na Uniwersytecie Śląskim w Katowicach, kontakt: danutakocurek@ interia.pl. 


\section{Wprowadzenie}

W

dobie cyberprzestrzeni i globalizacji znaczenia nabierają źródła autobiograficzne, do których należą m.in: pamiętniki, listy, wspomnienia, dzienniki i życiorysy zwane egodokumentami. Definicja egodokumentu została sformułowana w 1959 r. przez holenderskiego filologa i historyka Jacoba Pressera, który określił egodokumenty jako teksty, w których autor opowiada o swoich uczuciach, o życiu prywatnym i w sposób zamierzony lub niezamierzony ujawnia swoje ego ${ }^{1}$. Wyjątkowość tych źródeł polega na ich gatunkowej klasyfikacji, o ustalonych cechach wewnętrznych ${ }^{2}$. Koncepcję egodokumentu rozszerzył niemiecki historyk i metodolog historii Winfried Schulze, który stwierdził, że egodokumenty nie powinny być klasyfikowane wyłącznie gatunkowo, ale na podstawie cech wewnętrznych źródeł i wprowadził nowe określenie dla tego typu źródeł - samoświadectwo 3 .

Władysława Szulakiewicz podaje, że:

Ego-dokumenty to źródła, które zawierają autopercepcję i prezentację historycznego wydarzenia, osoby/osób, instytucji, obiektu. Są to teksty powstające jako efekt dobrowolnego lub przymusowego oświadczenia, raportu, sprawozdania, czyli dokumenty będące rezultatem przedstawienia osobistego świadectwa na temat siebie i innych osób oraz wydarzeń4.

Wspólną cechą wszystkich tekstów, które można określić jako egodokumenty, jest to, że jako oświadczenia (zeznania, wyznania) dobrowolne lub wymuszone, choć stanowią wycinek określonej rzeczywistości, dają pewien obraz postrzegania nie tylko innych, ale siebie samego (czyli autora) w rodzinie, społeczności, środowisku, kraju lub klasie społecznej. Zawierają informacje odzwierciedlające stosunek autora/ów do systemów wartości i ich ewolu-

1 Egodokumenty. Tradycje historiograficzne i perspektywy badawcze, red. W. Chorążyczwski, A. Pacevicius, S. Roszak, Toruń 2015, s. 7.

2 W. Chorążyczwski, A. Rosa, Egodokumenty - egodokumentalność - analiza egodokumentalna - spuścizna ego dokumentalna, w: Egodokumenty. Tradycje historiograficzne i perspektywy badawcze, s. 11.

3 Tamże, s. 12.

4 W. Szulakiewicz, Ego-dokumenty i ich znaczenie w badaniach naukowych, „Przegląd Badań Edukacyjnych", 1 (2013) nr 16, DOI: 10.12775/PBE.2O13.006, s. 67. 
cji na przestrzeni czasu. Ujawniają też stan wiedzy i doświadczenia życiowe. Wreszcie, egodokumenty uzasadniają, tłumaczą, usprawiedliwiają, przekonują o sensie zachowań indywidualnych i ludzkich ${ }^{5}$. Na podstawie analizy egodokumentów można przybliżyć daną osobę, ukazać świat wartości i zrekonstruować jej właściwości autobiograficzne oraz środowisko życia.

Egodokumentami interesują się przedstawiciele różnych nauk, szczególnie nauk społecznych i humanistycznych: historycy, kulturoznawcy, pedagodzy, socjolodzy, etnolodzy i filologowie. Sprzyja temu rosnąca popularność takich zjawisk jak np. historia mówiona, w której zwraca się uwagę na to, co poszczególni ludzie sądzą i mówią o otaczającym ich świecie. Przyczynił się do tego m.in. rozwój antropologii kulturowej, w ramach której mocno podkreślono zainteresowanie subiektywnym oglądem rzeczywistości, rozwijając badania nad mentalnością ${ }^{6}$.

Jak wspomniano, wśród egodokumentów są pamiętniki, które mogą być źródłem zastanym lub wywołanym. To dokumenty osobiste, które Florian Znaniecki określał jako pisemne wypowiedzi relacjonujące udział piszącego w pewnej sytuacji społecznej. Pamiętniki zawierają osobisty pogląd autora na te sytuacje, opisują przebieg wielu zdarzeń i zachowanie autora"7 . Dokumenty mogą być poddawane różnorodnym zabiegom analitycznym $\mathrm{i}$ interpretacyjnym.

Celem niniejszego szkicu jest prezentacja trzech egodokumentów - pamiętników nauczycieli Śląska Cieszyńskiego: Jana Kubisza, Jana Żebroka i Jana Szuścika, którzy przybliżają swoje życie i działalność edukacyjno-społeczną, opisywane na tle wydarzeń oświatowych, kulturowych i politycznych regionu. Należy dodać, że Śląsk Cieszyński w swojej kilkusetletniej historii zmieniał wielokrotnie przynależność państwową i administracyjną ${ }^{8}$. Skomplikowane dzieje

\section{Tamże.}

6 Kultura wsi w egodokumentach, red. H. Czachowski, V. Wróblewska, Toruń 2016, s. 8.

7 J. Szczepański, Odmiany czasu teraźniejszego, Warszawa 1973, s. 624.

8 W przeszłości obszar Śląska Cieszyńskiego znajdował się na pograniczu różnych organizmów państwowych: Królestwa Polskiego, krajów Korony św. Wacława, Królestwa Węgier, monarchii austriackiej, potem Austro-Węgier, z wchodzącymi w ich skład Morawami i Galicją, a także państwa pruskiego. W wyniku wojen śląskich i zawartych traktatów pokojowych w latach 1742 i 1763, przy Monarchii Austriackiej pozostały księstwa cieszyńskie i opawskie oraz południowa cześć karniowskiego. Obszar ten nazwano Śląskiem Austriackim, w odróżnienia od Śląska Pruskiego; D. Kocurek, W. Korzeniowska, Śląsk Cieszyński w latach 1741-1918 w aspekcie czynników integrujących i dezintegrujących regon. Studium monograficzne, Kraków 2013, S. 5. 
Śląska Cieszyńskiego oraz wielonarodowość, wielowyznaniowość i wielokulturowość odbiły się szerokim echem w wielu dziedzinach życia. Meandry historii, aspekty społeczne, religijne i oświatowe oraz pracę na rzecz społeczności lokalnej przybliżają pamiętniki wielu działaczy tego regionu.

Serię pamiętników, wspomnień i dzienników na Śląsku Cieszyńskim zapoczątkowali ks. Jan Muthmann w 1740 r. i pastor cieszyński Traugott Bartelmus (1735-1809) oraz pastorzy bielscy: Karol Schneider i dr Ryszard Wagner. Pamiętniki wspomnianych autorów pisane były w języku niemieckim. Wśród egodokumentów pisanych w języku polskim na szczególną uwagę zasługują: Dzienniki Andrzeja Cinciały z lat 1846-1853, Pamiętnik Pawła Stalmacha9 Wspomnienia i zapiski Pawła Bobka ${ }^{10}$ i Księga życia Walentego Krząszcza ${ }^{11}$. Pamiętniki, wspomnienia i dzienniki pozostawili po sobie m.in.: ks. dr Andrzej Buzek $^{12}$, ks. Dominik Ściskała ${ }^{13}$, Józef Pilch' ${ }^{14}$ J Jan Szczepański ${ }^{15}$.

\section{Jan Kubisz, Pamiętnik starego nauczyciela}

Wśród wielu egodokumentów ważne miejsce zajmuje Pamiętnik starego nauczyciela. Garść wspomnień z życia śląskiego w okresie budzącego się ruchu narodowego w b. Księstwie Cieszyńskim ${ }^{16}$ Jana Kubisza (1848-1929) ${ }^{17}$. Autor spi-

9 P. Stalmach, Pamiętnik, Cieszyn 1910.

10 P. Bobek, Wspomnienia i zapiski, Warszawa 1964.

11 W. Krząszcz, Księga życia, Międzyrzecze 1956.

12 Ks. dr A. Buzek był autorem m.in. Wspomnień ziemi piastowskiej, Cieszyn 1963.

13 Ks. D. Ściskała, Pamiętnik kapelana wojskowego, Cieszyn 1934.

14 J. Pilch, Dziennik. Zapiski bibliofila i dziejopisa z lat 1963-1995, Ustroń 2013.

15 J. Szczepański, Dzienniki z lat 1935-1945, opracował i wstępem opatrzył D. Kadłubiec, Ustroń 2009.

16 J. Kubisz, Pamiętnik starego nauczyciela. Garść wspomnień z życia śląskiego w okresie budzącego się ruchu narodowego w b. Księstwie Cieszyńskim, Cieszyn 1928.

17 Jan Kubisz (1848-1929) - nauczyciel, poeta, pamiętnikarz. Urodził się w Końskiej nad Olzą w rodzinie chłopskiej. Ukończył gimnazjum ewangelickie w Cieszynie, a następnie preparandę. Po uzyskaniu kwalifikacji nauczycielskich, pracował w szkole ewangelickiej w Gnojniku. Podejmował wiele działań edukacyjno-społecznych, m.in. w teatrze amatorskim przy Czytelni Ludowej w Cieszynie, publikował swoje utwory w „Gwiazdce Cieszyńskiej”, a od 1885 r. w „Przyjacielu Ludu”. Wydał tomik Niezapominajka: kilka wierszy dla szląskiéj młodzieży, w 1902 r. opublikował 
sywał wspomnienia z inspiracji ks. Franciszka Michejdy ${ }^{18}$ i od 1919 r. ogłaszał je na łamach „Posła Ewangelickiego”. Trzy lata po ich ukończeniu w 1925 r. wspomnienia przybrały formę książki. Jak pisze Katarzyna Szkaradnik, genologicznie najbliżej im do pamiętnika, czyli narracji ukierunkowanej - odmiennie niż autobiografia - na świat zewnętrzny. Oprócz własnego życiorysu autor panoramicznie nakreślił realia społeczno-narodowe Śląska Cieszyńskiego, a o siebie napomykał jako o uczestniku i świadku wielu wydarzeń ${ }^{19}$. Wspomniany Pamiętnik jest swego rodzaju lokalną biblią ${ }^{20}$ i funkcjonuje na prawach symbolu, nawet dla tych, którzy nie znają szczegółowo jej treści. Należy dodać, że Kubisz zasłynął jako nauczyciel, poeta ${ }^{21}$ i twórca powszechnie kojarzonych wierszy Ojcowski dom i Płyniesz, Olzo... (właśc. Nad Olza), które w wersji śpiewanej urosły do rangi nieoficjalnych hymnów Cieszyniaków - Polaków po obu stronach granicy państwowej22.

Pamiętnik Kubisza składa się z trzech głównych rozdziałów, w których autor przybliżył dom rodzinny, pobyt „w mieście”, drogę do zawodu nauczycielskiego, pracę w ewangelickiej szkole ludowej w Gnojniku oraz prezentował sprawy religijne i stosunki w szkolnictwie za czasów księdza Otto ${ }^{23}$. Warto podkreślić, że

tom zbiorowy $Z$ niwy ślq̨skiej, a w 1910 r. Pieśn o Grunwaldzie. Pod koniec życia wydał Pamiętnik starego nauczyciela. Zmarł w Gnojniku; B. Snoch, Górnośląski leksykon biograficzny, Katowice 1997, s. 130.

18 Franciszek Michejda (1848-1921) - urodził się w Olbrachcicach na Śląsku Cieszyńskim, działacz narodowy i społeczny, polski duchowny ewangelicki. Uczył się w gimnazjum ewangelickim w Cieszynie, a następnie studiował na Wydziale Teologii Ewangelickiej w Wiedniu, później w Lipsku i Jenie. Po ukończeniu studiów był wikariuszem w Bielsku, później w Brygidowie koło Stryja, w 1874 r. powrócił na Śląsk Cieszyński. Został wtedy pastorem zboru w Nawsiu. Wspierał wiele instytucji gospodarczych oraz towarzystw oświatowych. Był współzałożycielem „Przyjaciela Ludu”, „Dziennika Cieszyńskiego”, redaktorem „Rolnika Śląskiego”, „Przeglądu Politycznego”, prezesem Towarzystwa Ewangelickiego Oświaty Ludowej w Cieszynie; B. Snoch, Górnośląski leksykon biograficzny, Katowice 1997, s. 153-154.

19 K. Szkaradnik, Z powrotem do Kubisza. O fenomenie pewnego pamiętnika, „anthropos", 26 (2017) s. 67.

20 Tamże, s. 66.

21 B. Snoch, Górnośląski leksykon biograficzny, s. 130.

22 Tamże.

23 J. Kubisz, Pamiętnik starego nauczyciela. Garść wspomnień z życia śląskiego w okresie budzącego się ruchu narodowego w b. Księstwie Cieszyńskim. 
Kubisz często nawiązywał do ówczesnej sytuacji kulturowo-społecznej, pisząc m.in. o czynnikach integrujących lokalną społeczność:

[...] społeczność wiejską łączyła wspólna dola, wspólne zwyczaje, wierzenia, wspólny język, choć też nie brakło wpływów, któryby chciały rozbić tę serdeczną gromadę, powaśnić ja i rozdzielić. Skąd to pochodziła ta łączność niespożyta? Może niedawny ucisk pańszczyźniany łączy gminę w tę serdeczną gromadę, zacierając różnice wyznaniowe i społeczne. To też panował w gminie stosunek przyjacielski, bezinteresowna usłużność, a przede wszystkim gościnność ${ }^{24}$.

W kontekście reform oświatowych i szkolnictwa drugiej połowy XIX stulecia Kubisz przybliżał atmosferę, jaka panowała w ówczesnym gimnazjum ewangelickim w Cieszynie:

Zjeżdżała się do nas młodzież ewangelicka z całej prawie Austrii, a więc z Rakus, Czech, Galicji, Słowacczyzny, a nawet z zagranicy [...]. Ciągły antagonizm panował wśród młodzieży szkolnej, który od czasu do czasu z lada błahych powodów wybuchał zatargiem na tle narodowym. W klasach było zazwyczaj spokojnie, bo procentowo obcy znikali w większości tubylczej, ale poza szkołą łączono się narodowo i odrębną chodzono drogą. Na przykład Czesi, których było najwięcej, a mieszkali w alumnem, zwarli się w jeden blok i stanęli sztorcem do nas, tubylców. Rozpierali się jak na swoich śmieciach, byli brutalni wobec polskich współlokatorów, wyśmiewali się z polskiej mowy i dokuczali nam najnieznośniej. Męką było żyć z nimi. [...] Niemcy zaś żyli z nami na ogół spokojnie. Gimnazjum było niemieckie, ruch narodowy u nas jeszcze w powijakach, toż o jakichkolwiek niesnaskach na tle politycznym mowy być nie mogło ${ }^{25}$.

Autor opisywał konflikty pomiędzy młodzieżą różnych narodowości uczącą się w gimnazjum.

Autor Pamiętnika, jako nauczyciel, ukształtowany został przez zderzenie się tradycyjnych, związanych z rutyną szkolną, metod nauczania i wychowania z teoriami nowymi, wyrastającym od schyłku XVIII w. ze współczesnych

24 Tamże, s. 29.

25 Tamże, s. 111-112. 
osiągnięć rodzących się nowoczesnych nauk pedagogicznych ${ }^{26}$. Pamiętnik starego nauczyciela jest obrazem życia ludu śląskiego od Wiosny Ludów do pierwszych lat okresu międzywojennego, jego obyczajów i sposobu myślenia ${ }^{27}$. Trzeba zaznaczyć, że Pamiętnik nie jest wystarczającym źródłem do biografii pisarza, z uwagi na czynnik subiektywny, ale jest egodokumentem przydatnym badaczom historii Śląska Cieszyńskiego.

Lektura Pamiętnika Kubisza ukazuje autora jako pedagoga i jego wszechstronne umiejętności zarówno humanistyczne, jak i przyrodnicze, współzałożyciela miejscowego Towarzystwa Pedagogicznego, działacza Czytelni Ludowej na Śląsku Cieszyńskim, animatora działań patriotycznych, działacza narodowego i oświatowego. Należy dodać, że Kubisz autobiograficzną syntezę swego życia zawarł w zakończeniu Pamiętnika:

Służyłem sprawie ojczystej razem z innymi z całego serca, nie kłaniałem się cudzym bogom, ale służyłem siedząc na progu ojczystego Domu i ucząc dzieci polskiego ludu. I to mi dziś jedyną nagrodą, że mi tak służyć dano ${ }^{28}$.

\section{Jan Szuścik, Życiorys nauczyciela}

Do grona nauczycieli Śląska Cieszyńskiego, którzy pozostawili po sobie wspomnienia w formie pamiętnika, należy Jan Szuścik (1879-1940), autor Życiorysu nauczyciela. Pochodził z wielodzietnej rodziny chłopskiej z podcieszyńskich Gułdów. Mimo wykształcenia zdobytego w niemieckim seminarium nauczycielskim (tylko takie wówczas w Cieszynie istniało), pozostał wierny polskim tradycjom wyniesionym z domu zarówno jako nauczyciel, jak i działacz społeczny Macierzy Szkolnej ${ }^{29}$. W czasie pierwszej wojny światowej został powołany do armii austriackiej, znalazł się na froncie wschodnim i w niewoli rosyjskiej (przebywał na Syberii, osadzony w Tiumieniu). Po powrocie z wojny został członkiem Rady Narodowej Księstwa Cieszyńskiego z ramienia PSL, a w wyniku wyborów w 1922 r. uzyskał mandat posła do Sejmu Śląskiego pierwszej kadencji.

26 E. Buława, Etos nauczycielski Jana Kubisza a system wartości prezentowany przez „Miesięcznik Pedagogiczny”, „Pamiętnik Cieszyński”, 14 (1999).

27 C. R., Wspomnienie o Janie Kubiszu, „Zwrot”, 1998, nr 1, s. 4-5.

28 J. Kubisz, Pamiętnik starego nauczyciela, s. 312.

29 J. Golec, S. Bojda, Stownik biograficzny ziemi cieszyńskiej, t. 1, Cieszyn 1995, s. 245. 
Powierzono mu kierownictwo Zakładem Wychowawczym dla chłopców w Cieszynie. Od 1929 r. był członkiem Rady Gminnej Cieszyna. W marcu 1940 r. został aresztowany przez Niemców, a miesiąc później zginął w obozie koncentracyjnym w Oranienburgu ${ }^{30}$.

Szuścik pisał swój Pamiętnik w 1938 r. na konkurs Instytutu Pedagogicznego w Warszawie, w którym otrzymał drugą nagrodę. Pamiętnik składa się z czterech dużych rozdziałów, a zaczyna się od historii rodziny Szuścików, która osiedliła się na Śląsku Cieszyńskim w XVIII w., a kończy się na opisie sytuacji w Łazach (dziś dzielnica Orłowej) po przyłączeniu do Polski w 1938 r. Autor opisał dzieciństwo i młodość, naukę w szkołach w Krasnej i Cieszynie, pracę szkolną i pozaszkolną w Łazach i Boguminie. Na łamach Pamiętnika nakreślił konflikt polsko-czeski o Zaolzie po pierwszej wojnie światowej i w 1938 roku ${ }^{31}$. Trzeba dodać, że był on publicystą, który opublikował wiele artykułów na łamach „Głosu Ludu Śląskiego” i „Nowin Śląskich”.

Autor Pamiętnika był świadkiem wielu wydarzeń początku xx w., które przedstawił w sposób subiektywny na tle stosunków narodowościowych i politycznych na Śląsku Cieszyńskim ${ }^{32}$. Fakt historyczny, jakim był przewrót w 1920 r., tak opisał:

Rok 1920 - dzień 28 lipca - oto początek tragedii nie tylko Śląska zaolziańskiego, ale także początek tragedii polsko-czeskiej w ogóle. Utrata gór sudeckich przez Czechów na rzecz trzeciej rzeszy Hitlera bez wystrzału, to skandal historyczny, jakiego nie notują dzieje ludzkości. Są to konsekwencje bratobójczego najazdu czeskiego ze stycznia 1919 roku - inaczej Polska byłaby lat dwadzieścia pracowała wspólnie z Czechosłowacją i Czesi nie byliby utracili piędź własnej ziemi. Czyż jest do pomyślenia, by państwo liczące 15 milionów, uzbrojone od stóp do głów, zaprzepaściło część kraju z olbrzymiemi dobrami, nie broniąc się wcale i nie próbując nawet się bronić. Oto skutki zaślepionej polityki czeskiej, górującej w megalomanii ${ }^{33}$.

30 S. Zahradnik, Zaolziańskie ofiary okupacji hitlerowskiej $w$ byłych powiatach: czesko cieszyńskim i frysztackim, Opole 1988, s. 284.

31 W. Marcoń, Wstęp, w: J. Szuścik, Pamiętnik „Życiorys nauczyciela”, wybór i opracowanie W. Marcoń, Toruń 2013, s. 9-10.

32 Tamże, s. 10.

33 J. Szuścik, Pamiętnik, s. 239-140. 
Szuścik był bezkompromisowy w sądach. Wystarczy zwrócić uwagę na jego komentarz na temat wyborów w 1937 r.:

Przed rokiem kusiłem się nawet o stanowisko wiceburmistrza Cieszyna, lecz byłem za mądry dla przeciwników. Powodzenie w tym względzie mają raczej ludzie bardzo przeciętni, a nawet głupi ${ }^{34}$.

Analizując treść Pamiętnika, zauważyć można, że autor pisał o wielu sprawach, czasami błahostkach, które przybliżały życie na Śląsku Cieszyńskim przełomu XIX i XX w. Są to sprawy dotyczące m.in. głuchoniemego braciszka ${ }^{35}$, pierwszych miłości ${ }^{36}$, prowadzonych dyskusji na tematy wyznaniowe z kolegą ewangelikiem $^{37}$. Dzięki tym wspomnieniom można lepiej poznać i zrozumieć stosunki narodowościowe, religijne i polityczne regionu cieszyńskiego oraz ukazać autora jako krzewiciela języka polskiego, historii Polski, haseł niepodległościowych, działacza społeczno-oświatowego, o czym pisał w zakończeniu Pamiętnika:

„[...] siedzę w uporządkowanym po raz piętnasty moim królestwie i chwalę Boga, że mi dał łaskę dożyć wielu rzeczy, że dał ludzi, którzy pracę mą cenią, że dał mi Polskę, której mogę oddać najlepsze me siły i doświadczenie całego bogatego żywota" ${ }^{\prime 3}$.

\section{Jan Żebrok, Pamiętnik śląskiego nauczyciela}

Do generacji nauczycieli, którzy wnieśli duży wkład do literatury pamiętnikarskiej o zasięgu ponadregionalnym, należy Jan Żebrok (1883-1965), działacz społeczno-oświatowy, pochodzący z chłopskiej rodziny, absolwent Państwowego Gimnazjum w Cieszynie. Autor Pamiętnika śląskiego nauczyciela w latach 1905-1950 pracował m.in. w szkołach w: Marklowicach Górnych, Dąbrowie, Skoczowie i Cieszynie. Jako długoletni prezes Polskiego Towarzystwa Pedagogicznego, a później prezes Oddziału Powiatowego Związku Nauczycielstwa Polskiego w Cieszynie miał możność:

34 Tamże, s. 259.

35 Tamże, s. 63-67.

36 Tamże, s. 215-216.

37 Tamże, s. 138-139.

38 Tamże, s. 267. 
zapoznać się dobrze ze szkolnictwem na Śląsku w czasach zaborczych, jak i w latach późniejszych, aż do przejścia w stan spoczynku w roku $1950^{39}$.

W latach 1936-1939 i 1945-1948 działał aktywnie w Macierzy Szkolnej. Współpracował z „Dziennikiem Cieszyńskim” i „Miesięcznikiem Pedagogicznym". W czasie drugiej wojny światowej był więźniem obozu w Dachau. Oprócz Pamiętnika śląskiego nauczyciela opracował i przygotował do druku podręczniki szkolne dla klas III-VI, które zatytułował Nasze czytanki ${ }^{40}$.

Żebrok na łamach Pamiętnika pisał:

Od dłuższego czasu nosiłem się z zamiarem spisania własnych wspomnień i przeżyć i przekazania ich głównie moim dzieciom i wnukom. Wszak żyłem w okresie wielkich zmian politycznych, społecznych, kulturalnych i gospodarczych w ostatnich dziesiątkach lat na Śląsku Cieszyńskim, a których byłem nie tylko świadkiem, ale w pewnej mierze uczestnikiem. Niejednokrotnie zwracali się do mnie także koledzy jako do nestora nauczycielstwa, jak mnie często nazywają, z zachętą bym napisał coś w rodzaju pamiętnika starego nauczyciela znanego u nas poety Jana Kubisza. Wreszcie zachęcił mnie do podjęcia się niniejszej pracy ogłoszony przez Polską Akademię Nauk w Warszawie konkurs na pamiętnik nauczyciela na temat szkolnictwa i oświaty z okresu od pierwszej wojny światowej z roku 1914 do końca drugiej i okupacji ${ }^{41}$.

W Pamiętniku śląskiego nauczyciela opisywał lata swojej młodości, pracę pedagogiczną i nauczycielski ruch zawodowy na Śląsku Cieszyńskim. Przybliżał wydarzenia związane z przewrotem i najazdem czeskim. Sporo miejsca poświęcił okupacji niemieckiej i pobycie w obozie koncentracyjnym w Dachau, a potem w Zakliczynie w Generalnej Guberni, skąd powrócił do Cieszyna.

Układ Pamiętnika jest chronologiczny z niewielkim odchyleniami, np. w pewnych sytuacjach autor wybiega nieco w przyszłość, aby później ponownie cofnąć się do wydarzeń wcześniej opisywanych. Kompozycyjne uporządkowanie materiału w szesnastu rozdziałach, z których każdy ma od kilku

39 J.Żebrok, Pamiętnik śląskiego nauczyciela, oprac., wstęp i indeksy J. Miękina-Pindur, Cieszyn 2002, s. 13.

40 J. Miękina, Na macierzowym szlaku, Cieszyn 1983, s. 9.

41 Tamże, s. 13. 
do kilkunastu podrozdziałów, tematycznie stabilizuje narrację wokół zagadnień podanych w tytule rozdziału lub podrozdziału ${ }^{42}$. Jak podaje Jadwiga Miękina-Pindur, w Pamiętniku solidnie został opracowany aparat historyczno-statystyczny z odwołaniem się do źródeł i liczb, a to sprawia, że utwór jest pracą rzetelną i obiektywną, gdy chodzi o dane, ewidencję i statystykę. Świadczy o tym podrozdział zatytułowany Cieszyn po podziale, w którym autor podał szczegółowe dane dotyczące mieszkańców miasta:

Według spisu ludności z roku 1900, tj. w czasach austriackich liczył Cieszyn 22498 mieszkańców; z tego Niemców było 62\%, Polaków - 32,6\%, Czechów - 6,4\%. Przy spisie ludności w roku 1921 Cieszyn polski wykazał 15 268 mieszkańców, z tego było 62\% Polaków, 30\% Niemców, 6,6\% - Żydów. Znaczna część Niemców cieszyńskich przeniosła się dobrowolnie w pierwszych latach po podziale Śląska do Niemiec i Austrii albo do Czechosłowacji, gdzie spodziewali się prędzej ostać ze względu na poważną mniejszość narodową, jaką stanowi ludność niemiecka w obrębie tego państwa ${ }^{43}$.

Subiektywizm autora dostrzegamy tam, gdzie jest mowa o osobach, z którymi spotykał się, czy też tam, gdzie dokonuje interpretacji faktów ${ }^{44}$. Ważna sprawą w życiu Żebroka była walka o polskość i zagazowanie w działalność wspomnianego Towarzystwa Pedagogicznego w Cieszynie, o czym pisał:

walka naszego Towarzystwa o polski charakter szkoły, walka z renegactwem i zachłanną niemczyzna, to nie był nacjonalizm, lecz szczytna i ofiarna praca dla naszego ludu, celem podniesienia go z ciemnoty i zacofania na wyższy poziom kultury i świadomości narodowej ${ }^{45}$.

Należy dodać, że Pamiętnik ślaskiego nauczyciela ze względów politycznych nie mógł ujrzeć światła dziennego w okresie, gdy powstał. Wydany został drukiem 50 lat po jego napisaniu.

42 J. Miękina-Pindur, Wstęp, w: J.Żebrok, Pamiętnik śląskiego nauczyciela, s. 9.

43 J.Żebrok, Pamiętnik śląskiego nauczyciela, s. 116.

44 Tamże, s. 8.

45 Tamże, s. 136. 


\section{Podsumowanie}

Wspomniane pamiętniki prezentują biografię narratorów i ich zaangażowanie w życie społeczno-oświatowe oraz wskazują na fakt, że byli oni szermierzami polskości. Autorzy portretują ówczesną wielokulturowość lokalnej społeczności. Treści przekazywane przez autorów są naturalne i zarazem barwne. Wartość wzmiankowanych Pamiętników jest bezsprzeczna, ale analiza tych egodokumentów, jak pisze Władysława Szulakiewicz, wymaga od badaczy niezwykłej rozwagi w ogólnym odczytaniu tych źródeł. Należy wykazać ostrożność w wysuwaniu wniosków, ustaleniu faktów źródłowych o ludziach, wydarzeniach i instytucjach ${ }^{46}$. Chociaż pamiętniki są zapisami subiektywnymi, to swą faktografią wnoszą wiele materiału dokumentacyjnego do badań i opracowań źródłowych na tematy społeczne, polityczne, kulturowe, wyznaniowe, oświatowe związane z regionem na przestrzeni minionych lat. Pamiątki nauczycieli Śląska Cieszyńskiego mogą być cennym materiałem do badań biograficznych oraz przyczynkiem do historii, kultury i oświaty regionu.

Streszczenie: Skomplikowane dzieje Śląska Cieszyńskiego w XIX i XX w. przybliżone zostały w egodokumentach, do których należą pamiętniki nauczycieli Jana Kubisza, Jana Żebroka i Jana Szuścika. Źródła te, oprócz autobiografii prezentują wydarzenia społeczno-kulturowe, oświatowe i polityczne tego regionu. Wybrane treści pamiętników i ich rola w ukazywaniu kontekstu historycznego i pracy nauczycielskiej będą przedmiotem rozważań.

Słowa kluczowe: egodokumenty, biografie, Śląsk Cieszyński, pamiętniki, nauczyciele, Jan Kubisz, Jan Żebrok, Jan Szuścik.

\section{Bibliografia}

Bobek P., Wspomnienia i zapiski, Warszawa 1964.

Buława E., Etos nauczycielski Jana Kubisza a system wartości prezentowany przez „Miesięcznik Pedagogiczny”, „Pamiętnik Cieszyński”, 14 (1999), s. 20-40.

Buzek A., Wspomnień ziemi piastowskiej, Cieszyn 1963.

C. R., Wspomnienie o Janie Kubiszu, „Zwrot”, 1998, nr 1, s. 4-5.

46 W. Szulakiewicz, Ego-dokumenty, s. 79. 
Chorążyczwski W., Rosa A., Egodokumenty - egodokumentalność - analiza egodokumentalna - spuścizna egodokumentalna, w: Egodokumenty. Tradycje historiograficzne i perspektywy badawcze, red. W. Chorążyczwski, A. Pacevicius, S. Roszak, Toruń 2015, s. 7-21.

Egodokumenty. Tradycje historiograficzne i perspektywy badawcze, red. W. Chorążyczwski, A. Pacevicius, S. Roszak, Toruń 2015.

Golec J., Bojda S., Słownik biograficzny ziemi cieszyńskiej, t. 1, Cieszyn 1995.

Kocurek D., Korzeniowska W., Śląsk Cieszyński w latach 1741-1918 w aspekcie czynników integrujących i dezintegrujących regon. Studium monograficzne, Kraków 2013.

Krząszcz W., Księga życia, Międzyrzecze 1956.

Kubisz J., Pamiętnik starego nauczyciela. Garść wspomnień z życia śląskiego w okresie budzącego się ruchu narodowego w b. Księstwie Cieszyńskim, Cieszyn 1928.

Kultura wsi w egodokumentach, red. H. Czachowski, V. Wróblewska, Torun 2016.

Marcoń W., Wstęp, w: J. Szuścik, Pamiętnik „Życiorys nauczyciela”, wybór i opracowanie W. Marcoń, Toruń 2013, s. 9-10.

Miękina J., Na macierzowym szlaku, Cieszyn 1983.

Pilch J., Dziennik. Zapiski bibliofila i dziejopisa z lat 1963-1995, Ustroń 2013.

Roszak S., Egodokumenty - kilka uwag o polskich i europejskich doświadczeniach historiograficznych oraz metodologicznych, „Biuletyn Polskiej Myśli Historycznej”, 8 (2013), S. 27-42, DOI: 0.12775/BPMH.2013.001.

Snoch B., Górnośląski leksykon biograficzny, Katowice 1997.

Stalmach P., Pamiętnik, Cieszyn 1910.

Szczepański J., Dzienniki z lat 1935-1945, opracował i wstępem opatrzył D. Kadłubiec, Ustroń 2009.

Szczepański J., Odmiany czasu teraźniejszego, Warszawa 1973.

Szkaradnik K., Z powrotem do Kubisza. O fenomenie pewnego pamiętnika, „anthropos”, 26 (2017), s. 65-80.

Szulakiewicz W., Ego-dokumenty i ich znaczenie w badaniach naukowych, „Przegląd Badań Edukacyjnych", 1 (2013) nr 16, s. 65-83, DOI: 10.12775/PBE.2013.006.

Szuścik J., Pamiętnik „Życiorys nauczyciela”, Toruń 2011.

Ściskała D., Pamiętnik kapelana wojskowego, Cieszyn 1934.

Zahradnik S., Zaolziańskie ofiary okupacji hitlerowskiej w byłych powiatach: czesko cieszyńskim i frysztackim, Opole 1988.

Żebrok J., Pamiętnik śląskiego nauczyciela, oprac., wstęp i indeksy J. Miękina-Pindur, Cieszyn 2002. 